\title{
THE RELEVANCE OF ANTHROPOLOGY IN MANAGEMENT EDUCATION IN INDIA
}

\author{
N U KHAN \\ Jamia Millia Islamia (A Central University), NeW Delhi \\ SIGAMANI PANNEER \\ CENTRAL UNIVERSITY OF TAMIL NADU, THIRUVARUR \\ SARIKA TOMAR \\ Jamia Millia Islamia (A Central UniVersity), New Delhi \\ SHWETA MALHOTRA \\ Jamia Millia Islamia (A CENTRAl UniVERsity), New Delhi
}

\begin{abstract}
This paper explores the significance of anthropology in management education. It also aims to develop an insight into the benefits that the business would accrue by introducing anthropology to management education. Globalization has a multifaceted bearing on education-it endorses new tools and techniques in this area. But whether education can prepare citizens to face the new challenges will depend upon the quality of education. Business education in India is undergoing a profound paradigm shift to respond to the challenges arising out of the rapidly changing business environmental factors.
\end{abstract}

Keywords: anthropology, globalization, management education, human resources, paradigm shift, India

\section{Introduction}

As business leaders try to navigate and rebuild economies attacked by the global meltdown, business schools around the world are reassessing how to train future managers in the middle of unparalleled obstacles. Instead of wasting more time on reviewing things done earlier, it is better 
to reinvent management education (Westerbeck, 2010). On completing their management education, graduates are expected to become liberated intellectuals and proficient problem solvers. Hence the role of a teacher is to facilitate students so that they learn the art of adapting to dynamic business situations. The present education system and its over-emphasis on gathering information have tarnished the capability to look at situations from a holistic and broader perspective (Ajith, 2012).

\section{Business Education in India}

Business education in India was started in 1954 by the Indian Institute of Social Welfare and Business Management in Calcutta. It was a parttime course for practicing executives. Similar programs were started in the Delhi School of Economics at Delhi University, and at Madras and Andhra Universities. The first Institute of Management was set up in Calcutta in November, 1961 in collaboration with the Alfred P Sloan School of Management of MIT, USA. In June 1962, the Indian Institute of Management (IIM) was established at Ahmedabad in collaboration with the Harvard Business School, USA. Later four more IIMs were set up at Bangalore 1972, Lucknow 1984, and Indore and Kozikode 1997. With the setting up of the first two IIMs, many other university departments started management programs at Master's and Doctoral level.

Business education has been widely recognized as one of the most important means of development. Management education facilitates the connection between economic development, organizational efficiency, and organization-wide performance of employees. Managers have a vital role to play in determining national and organizational success. As a result, business schools have incorporated new disciplines and updated their content to train their graduates. Business education has been imparting formal business skills to a wide range of business leaders, and striving towards the creation of knowledge, skills and competencies and many more things which make management education compulsory for organizations as well as individuals. Business education in India is undergoing a profound transition, and this transition is driven by globalization, technology, demographics and various other social imperatives. It is the youngest and the most popular discipline of all the social sciences in India. Contrary to the trend in Western countries, management education in India has been gaining greater mind-share as well as market-share during this period. It is quite evident that management education has been occupying center-stage of the professional education arena (Sougata and Sinha, 2005). The rise of India 
as an economic superpower has increased the demand for high-quality managers who can supervise, manage and increase the growing business of India where business education can no longer be driven by Western concepts and theories. There is a need to challenge and create an indigenous model of the management curriculum, and synchronization to Indian culture is what needs to be examined.

The country aims to join the league of developed nations by the year 2020, which requires that not only a vivacious economy driven by information has to be steered, but also a new society with righteousness prevalent has to be established. Moreover, challenges in professional education are no longer only nation-centric. They have already attained global dimensions. Hence, higher education requires refurbishing so as to make it more relevant to changing business demands. Also, the quality aspect of management education cannot be compromised just to meet the numerical criteria. Hence to fulfill the demands of society, the quality and numbers of business education graduates have to complement each other and none of them can be ignored.

\section{Changing Dimensions of Indian Business}

Indian and global business milieus are fluctuating with great speed. The marketplace today is multifarious, intertwined, and rapidly transforming itself. The Indian economy has become the focal point of business as the economies of the world have realized its potential to govern business and influence it in the future. Further, Indian firms are also expanding their boundaries and capabilities through increased mergers, acquisitions, joint ventures and so on. The different parts of the globe are now converging where India has a major role to play and is increasingly becoming the focal point of business activity.

The current pace of globalization, interdependence, technical innovation and competition is forcing business leaders to constantly rethink their strategies and long-established business practices. Companies have realized that it is not only the global approach which makes them successful, but also an understanding of local conditions - which tend to be highly diverse, both culturally, and socio-economically. Today's businesses are dealing across political and cultural frontiers. The human component has become multicultural, not only in multinational firms but also in domestic firms. These human elements reflect more than one organizational culture. Hence, it is important to properly understand these cultural differences, ignorance of which may lead to bad business. There are many cases in which organizations have failed owing to the failure to grasp the different 
cultural environments. New business thinking demands a deeper understanding of the culture. On the other hand, Indian firms growing overseas must now get hold of new skill-sets and mind-sets that are more suitable to the business environment at a global level.

On a day-to-day basis, organizations deal directly or indirectly with human beings as groups, communities, employees, consumers, clients, and institutions. This reminds us of the complexity underlying human behavior. Behaviors and organizations are shaped by the interplay of interpersonal interactions. Besides, the rapidly changing nature of the global workforce has aggravated the complexity of the situation. This is happening because the nature of work is altering. Until recently, issues which were considered unimportant, like retention, attrition, and succession planning, today occupy the centre stage and require another look at the fundamentals on which organizations are formed. All of these factors require a new type of leadership, both for multinationals operating in India, and for the new breed of Indian MNCs.

\section{Dimensions of Management Education}

Business education has a defined focus of developing managerial competence. This is attained by: (1) acquiring knowledge and learning to use this knowledge in dealing with managerial tasks; (2) a conscious effort to develop insights so that a person can handle problems in an objective manner; and (3) developing capabilities such as analytical, diagnostic and problem solving skills, and ability to communicate effectively (Dayal, 2002). This objective cannot be achieved with fixed curricula which do not allow business school graduates to develop their diagnostic and problemsolving skills.

Business education in India is imparted mainly in the classroom. Business graduates have very little exposure to industry while they pursue their education. In order to provide a competitive advantage to organizations, it is important for these graduates to understand the ground realities of a business from day one. The program has to include assignments, projects, dealing with real-time issues and feedback to students on their performance in these areas. Students have to develop self-confidence by interacting with others, through opportunities for introspection, and by several relevant planned inputs. Business graduates need to learn the application of theories and concepts to real life situations.

Management education already draws knowledge from a large number of theoretical and applied areas of study. Theories and concepts derived from behavioral, biological, quantitative areas and applied subjects need to 
be integrated. Business problems cannot be solved or understood by the framework provided by any one academic discipline. They may be caused by an interplay of economic, behavioral and technological aspects. Diagnosing the situation may require integrated perspective or interdependence between several academic areas. Problem analysis, diagnosis and anticipation of events, etc., often require understanding the interplay of such factors. Considering the nature of the organizational processes, it is imperative for business educators to employ a variety of teaching methods that can encourage students to integrate knowledge. Business graduates should be encouraged to take up research work to better understand the application of the concepts. It is important for them to shift their focus from primarily subject discipline to application. Educators of business schools should focus on developing appropriate teaching methodology and teaching material to impart meaningful and contextual knowledge to students.

Management education prepares a student for a managerial career. It imparts knowledge that is pertinent for enhancing capabilities to use this knowledge in problem analysis, diagnosis, anticipating events, and in decision-making (Dayal, 2002). The managerial role also entails being conscious of the needs of not just the organization, but of society at large. Management education has to provide strong conceptual and theoretical orientation to students that they are able to use in their day-to-day work. There is persuasive data to suggest that understanding the concepts does not always guarantee the use of these concepts in dealing with day-to-day situations. The process of transferring knowledge to action is a distinct and independent exercise.

Management education as a professional program of study should prepare a student to take on managerial responsibility as a professional. In the emerging context, educational programs must prepare a student to deal with the national and the global issues with an understanding of crosscultural differences. In substance these are the core concerns of education for management. 
Table 1: Paradigm Shift in Management Education

\begin{tabular}{|c|c|c|c|c|c|}
\hline Purpose & Curriculum & $\begin{array}{c}\text { Inter- } \\
\text { disciplinary } \\
\text { Approach }\end{array}$ & $\begin{array}{l}\text { Research } \\
\text { Culture }\end{array}$ & $\begin{array}{c}\text { Learning } \\
\text { Environment }\end{array}$ & $\begin{array}{l}\text { Learning } \\
\text { Methods }\end{array}$ \\
\hline $\begin{array}{c}\text { Fixed } \\
\text { Curriculum }\end{array}$ & $\begin{array}{l}\text { Fixed } \\
\text { Learning } \\
\text { Routine }\end{array}$ & $\begin{array}{l}\text { Management } \\
\text { Theories and } \\
\text { Concepts }\end{array}$ & $\begin{array}{l}\text { Theoretical } \\
\text { Knowledge }\end{array}$ & $\begin{array}{l}\text { Shift from } \\
\text { theory to } \\
\text { application }\end{array}$ & $\begin{array}{l}\text { Transfer of } \\
\text { knowledge to } \\
\text { Action }\end{array}$ \\
\hline $\begin{array}{c}\text { Defined } \\
\text { Focus } \\
\text { Flexible } \\
\text { Curriculum } \\
\text { Acquiring } \\
\text { knowledge } \\
\text { Developing } \\
\text { insights } \\
\text { Developing } \\
\text { diagnostic } \\
\text { and } \\
\text { problem } \\
\text { solving } \\
\text { skills }\end{array}$ & $\begin{array}{c}\text { Having } \\
\text { projects } \\
\text { dealing with } \\
\text { live } \\
\text { problems }\end{array}$ & $\begin{array}{c}\text { Draws } \\
\text { knowledge } \\
\text { from other } \\
\text { disciplines- } \\
\text { Theories and } \\
\text { concepts } \\
\text { derived from } \\
\text { behavioural, } \\
\text { biological, } \\
\text { quantitative } \\
\text { and } \\
\text { qualitative } \\
\text { areas }\end{array}$ & $\begin{array}{l}\text { Learner's } \\
\text { Autonomy } \\
\text { Application } \\
\text { of array of } \\
\text { teaching } \\
\text { methods- } \\
\text { Contemporary } \\
\text { teaching and } \\
\text { research } \\
\text { methods } \\
\text { Contextual } \\
\text { and Choice } \\
\text { based } \\
\text { Learning } \\
\text { Developing } \\
\text { Culturally } \\
\text { sensitive } \\
\text { management } \\
\text { professional }\end{array}$ & $\begin{array}{l}\text { Faculty to use } \\
\text { various } \\
\text { methods to } \\
\text { impart } \\
\text { relevant } \\
\text { knowledge } \\
\text { Learner's } \\
\text { Autonomy } \\
\text { and Flexible } \\
\text { Learning } \\
\text { Environment }\end{array}$ & $\begin{array}{l}\text { Experiential } \\
\text { Learning } \\
\text { Collaborative } \\
\text { Learning }\end{array}$ \\
\hline
\end{tabular}

Developed from Sources: (Dayal, 2002)

\section{Pitfalls in Management Education}

India has always followed the West as far as management education is concerned. As a result, the curriculum is more global than local. Management education in India still focuses on analytical models to solve complex business situations. These models are not suited to handling the ambiguity and high rate of change facing many industries today. They also become irrelevant when it comes to developing understanding human and socio-cultural elements of business organizations, which are daily becoming significant. Business educators have always faced the dilemma of academic rigor pitted against practical relevance. Only capable managers can provide sustained competitive advantage to organizations in a rapidly changing business environment. Business programs across the nation recognize the need to change in response to external pressure from 
stake-holders. Business organizations persist in changing themselves in reaction to various factors and the obstacles posed by rising competition, globalization of business, and swift alterations in information technology. This paradigm shift can longer be stopped in this fast-paced world. But what we need to do is to try and cope with these changes and incorporate them into the Indian business education system as quickly as possible. The curriculum followed by business schools in India is not sufficiently training individuals for the challenges they are exposed to as professional managers. Business schools in India should focus on developing a curriculum that should put together the different academic disciplines for creating managers competent of making ethical and commercially feasible choices in a unified world.

Another challenge India is facing is an immense skills-gap, signifying that the majority of graduates don't have employable skills in any sector based on an industry yardstick. This has ignited growing anxiety about the disparity between universities and the requirements of the job market. As the labor market shrinks for graduates in all sectors-manufacturing, technology, hospitality or corporate-getting employment becomes an issue. Business School graduates, apart from technical skills, also lack socio-economic knowledge. There is a wide gap between their IQ and EQ which is required for understanding today's business environment. There is a detachment between the skills and aptitude of the majority of graduates and the needs of industries. While some of the top Indian institutions, both private and government-funded, have begun to focus on enhancing the soft, and technical, skills of graduates, many of the institutions are still lagging behind industry expectations. Business education in India focuses on providing theoretical concepts and they do not try and shift their focus to providing hands-on exposure to students. The only major exposure that students get during their two year full-time course is through internships, which usually last for around two months, which is too short a time to gauge the concepts of management and start working practically. Business schools should focus on imparting mainstream education which would further develop a broader set of leadership and management capacities in professional managers.

Business Education in India does not have a culture that is supportive of research. It has been found that in low-ranking B Schools in India, students are not encouraged to do research work, with the result that their understanding of the field is limited to what is already there. A research society needs a research scheme. Such a society will become a reality only when it becomes an organizational precedence and there is conviction from senior management for building that. Leaders of Indian management 
education are quickly realizing that they must look outward and inward both to train business leaders of tomorrow.

\section{Anthropology in Management Education}

Anthropology is a discipline that has developed a wide array of qualitative techniques for understanding people and their behaviors. Until recently, researchers rated quantitative methods above analytical or qualitative ones (Tian and Walle, 2009). Business anthropology incorporates the use of qualitative and ethnographic methods to investigate organizational phenomena. Specific tools unique to anthropology include participant observation, informal and structured interviews, and other "naturalistic", informal, and face-to-face methods of investigation. Business anthropologists play a key role in developing culturally sensitive policies and strategies in a world that is increasingly typified by cross-cultural contacts (Jordan, 2003; Ybema et al. 2009). Business anthropology is defined as a practical field in which anthropologists apply anthropological theories and methods to identify and solve real business problems in everyday life. Business anthropologists include all anthropologists who study business fields, including management, operations, marketing, consumer behaviour, organizational culture, human resources management, international business, and so on through anthropological methods, particularly through ethnographic methods. Business anthropologists play a vital role in the business world by supporting corporations in building up ethically correct ways of carrying out business with suppliers, business partners and customers (Baba 2006; Tian et al., 2013). 
Table: 2 Conceptual Framework

\begin{tabular}{|c|c|c|c|}
\hline $\begin{array}{l}\text { Indian } \\
\text { Business: } \\
\text { Changing } \\
\text { Dimension }\end{array}$ & $\begin{array}{l}\text { Changes } \\
\text { Needed in } \\
\text { Business } \\
\text { Education }\end{array}$ & $\begin{array}{l}\text { Role of } \\
\text { Anthropology } \\
\text { in Business } \\
\text { Education }\end{array}$ & Outcomes \\
\hline $\begin{array}{l}\text { Complex and } \\
\text { interlinked }\end{array}$ & $\begin{array}{l}\text { Deeper } \\
\text { understanding } \\
\text { of culture }\end{array}$ & $\begin{array}{l}\text { Helps in } \\
\text { understanding } \\
\text { people and their } \\
\text { behaviour better }\end{array}$ & $\begin{array}{l}\text { Cullturally } \\
\text { aware } \\
\text { Management } \\
\text { Professionals }\end{array}$ \\
\hline $\begin{array}{l}\text { Multicultural } \\
\text { environment }\end{array}$ & $\begin{array}{l}\text { Independent } \\
\text { thinking and } \\
\text { problem } \\
\text { solving } \\
\text { approach }\end{array}$ & $\begin{array}{l}\text { Realistic and } \\
\text { contextual } \\
\text { approach } \\
\text { towards problem } \\
\text { solving }\end{array}$ & $\begin{array}{l}\text { Develop } \\
\text { culturally } \\
\text { sensitive } \\
\text { policies and } \\
\text { strategies }\end{array}$ \\
\hline $\begin{array}{l}\text { Involvement } \\
\text { and interaction } \\
\text { with more } \\
\text { stakeholders }\end{array}$ & $\begin{array}{l}\text { Focus on sector } \\
\text { and domain } \\
\text { specific } \\
\text { knowledge }\end{array}$ & $\begin{array}{l}\text { Focus on } \\
\text { Cultural } \\
\text { awareness and } \\
\text { Intercultural } \\
\text { skills }\end{array}$ & $\begin{array}{l}\text { Ability to } \\
\text { diagnose and } \\
\text { solve real } \\
\text { business } \\
\text { problems }\end{array}$ \\
\hline $\begin{array}{l}\text { New behaviours } \\
\text { and emerging } \\
\text { human } \\
\text { dynamics }\end{array}$ & $\begin{array}{l}\text { Field studies } \\
\text { and } \\
\text { experimentation } \\
\text { of concepts }\end{array}$ & $\begin{array}{l}\text { Understanding } \\
\text { the cultural } \\
\text { differences of } \\
\text { various } \\
\text { stakeholders }\end{array}$ & $\begin{array}{l}\text { Better } \\
\text { understanding } \\
\text { of public } \\
\text { domain }\end{array}$ \\
\hline
\end{tabular}

Today, in the globalized world, there is a significant need for anthropologists in business consulting, organizational behavior, human resources management, competitive intelligence, globalization, product design and development, marketing and consumer behavior studies (Baba 2014; Jordan 2010; Tian et al., 2013). Considering the relevance of business anthropology in the present, ever-changing business scenario, it is imperative for business schools to provide this understanding to the graduates about the reasons for individual behavior, the functioning of organizations, and consumer behavior at large (Jordan 2003; Tian et al., 2013). Business schools, as well as educators, can effectively apply anthropological theories and methods to their teaching practice, and in fact many business schools have started to remodel their curricula with the use of anthropological contributions (Tian, 2014; Tian and Walle, 2009; Tian, 2005). It is therefore necessary to craft a proposal to expand anthropological theories for practical utility, to develop new theories from empirical data 
and to present ethnographic accounts of business organizations, as well as to provide a forum for work concerned with qualitative business analysis inspired by anthropological theory and methods (Denny and Sunderland, 2014).

Business anthropologists take a "holistic" approach to studying human behavior surrounded by social, historical, spatial and economic frameworks. In this way, micro-studies of employees and customers are connected to meso and macro societal-level matters. They assume the social construction of cultural differences, which can be used strategically in cultural collaboration in strategic alliances and mergers (Marrewijk, 2009). Increasingly, the world sees anthropologists being actively involved in management topics and helping organizations to solve problems. These specialists help organizations in distinct roles such as researcherconsultants, organizational change advisers, cross-cultural specialists or cultural brokers (Tian and Walle, 2009). The globalization of business is creating new and unique situations involving personalities, organizations, communities and cultures. It means new opportunities to observe, analyze and interpret human dynamics in different circumstances. Hence, it has become imperative for business managers to study cultures and communities, i.e. learning from people and sharing their knowledge. The new thinking about business emphasizes cultural awareness and intercultural skills. Most business managers do not care to learn from people or cultures. Business education can always develop an interdisciplinary approach and expose business managers to qualitative methods of cultural anthropology, also known as social anthropology. As anthropology studies qualitative information regarding people, their habitats, communities, values, habits and aspirations, this information can be used as a tool in decision-making. Business education can apply anthropological knowledge in two ways: (1) business schools could encourage graduates to take up a topic of interest, and conduct in-depth studies of a particular business stakeholder, such as employees or the community, to develop a better understanding of the public domain; and (2) business schools can also collaborate with industries and persuade students to take up studies which focus on cultural differences and an intercultural approach. As social structures and cultural frameworks are constantly changing, there is a need for business graduates to develop cultural awareness and intercultural skills. This would also make them more sensitive towards cultural differences. Anthropology would help future managers to skillfully merge different sources of information and analysis, creating added value. This is possible by introducing some aspects and methods of anthropology into the business-education curriculum, and by 
providing opportunities to students and making the program more realistic and contextual.

\section{Road Map Ahead}

Business schools in India have an arduous accountability of taking education to a higher level with a strong quality orientation, keeping in mind the changes that are happening in and around the business. This has to begin with a change in the curriculum which should reflect the local scenario apart from global practices. The curriculum should be designed in such a way that it has authority to solve local complications in business administration, besides looking at long-term needs. The curriculum should also have a strong focus on sector/domain-specific knowledge and tools of management. While developing the curriculum, it is important to take inputs from the relevant industry to make it more industry-specific.

The reforms in management education should primarily focus on fostering creativity through curriculum modifications. Live projects which form the core of progressive evaluation must be given priority in the evaluation. The traditional way of lecturing should be replaced by progressive methods where the learner is at the center of the action (Chebolu, 2013). Another area that needs attention in business education is transforming the role of the faculty from "deliverers of knowledge" to "facilitators of learning". Business schools need to redefine the roles and tasks more in consonance with learning outcomes than merely delivering concepts and theories. The role of the facilitator should be to enhance student participation in the learning process. Innovative methods of disseminating knowledge should be introduced and learning should become more experiential and collaborative. Business degrees should have more space for live projects and industrial internships, which would in turn enhance the understanding of future management professionals. The basics like "knowledge", "skills" and "attitudes" need to be tested in a complete form as part of the industrial internships and live projects that are offered to budding management professionals.

The relevance of management education can be increased by incorporating the cultural dimension of context with what is being taught within the four walls of a classroom. Anything taught without a background becomes blurred in terms of learning outcomes and may not be as useful for learners. As such, ingraining cultural relativity to management education is found to be the primary requirement as the businesses and organizational fineness derives vigor from these ground rules if they are appropriately contextualized (Chebolu, 2013). 


\section{Conclusion}

In today's globalised world, human resources are the real focus. It is important to understand the culture, and the cultural differences, in business organizations. Business Anthropology would help management graduates become better at interacting with other people, and understanding their wants, needs and interests. It would make them interact better with their co-workers. Anthropology helps in an impartial investigation of any given state of affairs and aids a manager to understand things from human viewpoint. This results in better decision-making, ensuring good hiring, adept policies, and generates a well-educated workforce.

\section{References}

Ajith, P. (2012). B-Academic Scene: India to lead? SCMS Journal of Indian Management Vol. IX, No.11.

Baba, M. (2006). Anthropology and Business, In: H James HJ Birx (Ed.): Encyclopedia of Anthropology. Thousand Oaks, CA: Sage Publications, pp. 83-117.

Baba. M.L. (2014). De-anthropologizing ethnography: A Historical Perspective on the Commodification of Ethnography as a Business service. In: RM Denny, PL Sunderland (Eds.): Handbook of Anthropology in Business. Creek, CA: Left Coast Press, pp. 43-68.

Chebolu, R (2013). Reinventing Management Education in India: An Objective Framework. The IUP Journal of Soft Skills, Vol. VII, No. 1.

Dayal, Ishwar. (2002). Developing Management Education in India. Journal of Management Research. Volume 2, Number 2.

Denny, R.M. Sunderland, P.L. (eds.) (2014). Handbook of Anthropology in Business. Creek, CA: Left Coast Press.

Irshad Nazeer, I. (2012). Re-engineering for Excellence: B-Education. SCMS Journal of Indian Management Vol. IX, No.11.

Jordan, A. (2003). Business Anthropology: Prospect Heights. Illinois: Waveland Publishers.

- (2010). The Importance of Business Anthropology: Its Unique Contributions, International Journal of Business Anthropology. Vol. 1, No. 1.

Kumar, M. and Jha S. (2012). Revitalising Management Education in India: A Strategic Approach. Journal of Management and Public Policy, Vol. 3, No. 2.

Kumar, M. and Shweta. (2011). Management Education in India: Issues and Challenges. Journal of Management and Public Policy. Vol. 3, No. 


\section{1, July-December 2011, pp. 5-14}

Lang, James and J.E. Dittrich. (1982). Information, Skill Building and the Development of Competence: An Educational Framework for Teaching Business Policy. Academy of Management Review. 7 (2): 269-279.

Rojas D., Tian R.G., Zhou D., Van Marrewijk A.H. (2010). Editorial Commentary. International Journal of Business Anthropology, Vol. 1, No.1.

Sougata, R. and Sinha, A. (2005). Management Education. Let a Thousand Flowers Bloom. Decision Vol. 32, No. 2.

Tian G. (2014). Business Anthropology in China. In: RM Denny, PL Sunderland (Eds.): Handbook of Anthropology in Business. Creek, CA: Left Coast Press, pp. 556-570.

Tian, R.G. (2005). Anthropological Approach to Consumer Behaviour: A Marketing Educational Case of Teaching and Learning. Journal of Advancement of Marketing Education 7, pp. 36-46.

Tian R.G., Van Marrewjik A.H., Lillis, M. ( 2013). General Business Anthropology. 2nd Edition. Miami, FL: North American Business Press.

Tian R.G., Walle A. (2009). Anthropology and Business Education: Practitioner Applications for a Qualitative Method. International Journal of Management Education, 7(2): 59-67.

Tian, R.G., Senguder (eds.): Perspective in Consumer Behavior: An Anthropological Approach. Fort Worth, TX: Fellows Press of America, Inc., pp. 45-57

Van Marrewijk, A.H. (2009). Gezamenlijke cultuurverschillen De bedrijfsantropologie van crossculturele samenwerking in complexe projecten. Oratie Faculteit der Sociale Wetenschappen van de Vrije Universiteit Amsterdam.

Westerbeck, T. (2010) The Future of Management Education? India: 2010. (Retrieved on 23rd June 2011)

http://www.businessweek.com/managing/content/sep201ca2010093_5 20557.htm>.

Ybema S., Yanow D., Wels H., Kamsteeg F. (2009). Organizational Ethnography. Studying the Complexities of Everyday Life. London: Sage. 
